\title{
USING POLYMERASE CHAIN REACTION TECHNIQUE (PCR) FOR DETECTION BRUCELLA MELITENSIS IN ABORTED EWES' MILK IN NINEVEH, IRAQ
}

\author{
RAAD A. AL-SANJARY*; HADEEL A. MOHAMMED ${ }^{* *}$ and MOHAMMAD O. DAHL ${ }^{* *}$ \\ ${ }^{*}$ Department of Veterinary Public Health, University of Mosul, Mosul, Iraq \\ ** Department of Internal and Preventive Medicine, College of Veterinary Medicine, University of Mosul, Mosul, Iraq \\ Email: ralsanjary61@yahoo.com
}

\section{ABSTRACT}

Received at: 26/12/2013

In this study, polymerase chain reaction technique (PCR) used to detect Brucella melitensis in aborted ewes' milk in Nineveh Province, Iraq using species specific primers of $B r$. melitensis. Fifty aborted ewes were involved. Blood and milk samples were taken from each ewe. Blood samples used to detect Brucella antibodies in serum using RoseBengal plate test (RBPT), whereas PCR were applied on the milk samples to detect $B r$. melitensis using one pairs of specific primers for the strain of Br. melitensis. Results indicate 35 out of 50 samples $(70 \%)$ positive reaction by RBPT. From these 35 samples: 26 samples $(74.3 \%)$ were positive by PCR, while 9 samples $(25.7 \%)$ were negative. Samples that showed negative reaction by RBPT (15 out of 50 "30\%") revealed 8 samples $(53.3 \%)$ positive by PCR and 7 samples $(46.7 \%)$ were negative. The total number of milk samples that gave positive reaction by PCR (Br. melitensis) were 34 out of $50(68 \%)$ distributed on Nineveh's regions between $50-100 \%$. The study concluded that using an accurate tests, such as species-specific PCR technique, is an important for reflecting an accurate incidence; since PCR revealed that $B r$. melitensis existed in aborted ewe's milk in a high percentage in Nineveh, Iraq, which has a public health importance.

Key word: Brucella melitensis, sheep, milk, PCR

\section{INTRODUCTION}

Brucellosis is a contagious bacterial infection of livestock, with important effects on both public health and animal health and production. It is continues to be of great health concern and economic importance worldwide (Anonymous, 2001; Ibrahim et al., 2012). Infection in animals frequently results in abortion and diminished milk production (Culter et al., 2005). Brucella organisms localize in the supra-mammary lymph nodes and mammary glands in $80 \%$ of infected animals, which continue to excrete these pathogens in their milk throughout their lives and have a significant role in the epidemiology of the diseases (Abd El Razik et al., 2007). Therefore, man is infected by animal's brucellosis through direct or indirect by ingestion of animal products as after drinking raw milk or eating unpasteurized cheese (Celebi et al., 2007).

The disease presents a great variety of clinical manifestations, making it difficult to diagnose clinically. Therefore, the diagnosis must be confirmed directly by isolation, or indirectly by the detection of immune response against its antigens (Anonymous, 2001). Bacteriological methods depends on the viability and numbers of Brucella in the sample. Thus, culture methods are not always successful as they are timeconsuming and the handling of microorganism is hazardous (Refai, 2003; Kazemi et al., 2008) and serological methods are not conclusive; because not all infected animals produce significant levels of antibodies, and because cross-reaction with other bacteria can give false negative results (Abd El Razik et al., 2007; Ilhan et al., 2008). However, these methods are not wholly satisfactory, PCR assay has been used as an accurate and sensitive assay for detection of Brucella spp in a wide variety of clinical samples; such as, blood, milk, semen, and aborted fetuses even if samples contain low number of brucella (Anonymous, 2001; Dehkordi et al., 2012).

Bucellosis in Mosul, Iraq is a widespread, and many researches have been performed using various diagnostic methods in different samples and different animal species (Al-Farwachi et al., 2009; Al-Obaidi et al., 2009; Rhaymah et al., 2010 and Al-Farwachi et al., 2010). The diagnosis of brucellosis in sheep using serum and bacterial culture by PCR has been done in Mosul (Mohammad, 2006), while Brucella spp antibodies in raw milk has been detected using ELISA in sheep and goat (Al-Obaidi et al., 2009). The purpose of this study was to investigate the viability of the species specific PCR assay as a diagnostic tool for the detection of $B$. melitensis DNA in the milk of sheep after abortion using specific primers and comparing its results with the Brucella antibodies in serum using Rose-Bengal test in the same animal in Nineveh Province, Iraq.

\section{MATERIALS and METHODS}

Fifty aborted ewes were involved in this study. Blood and milk samples were taken from each ewe. Blood samples used to detect Brucella antibodies in serum using 
Rose-Bengal plate test (RBPT), whereas polymerase chain reaction technique (PCR) were applied on the milk samples to detect Brucella melitensis using one pairs of specific primers for the strain of Br. melitensis.

\section{Preparation of milk samples for PCR:}

Milk samples were prepared to improve extraction and purification of bacterial DNA from milk according to Romero and Lopez-Goni (1999): $10 \mathrm{~mL}$ of milk centrifuged at $3000 \mathrm{~g} / \mathrm{min}$ for $15 \mathrm{~min}$. The supernatant was removed and discarded. The pellet was resuspended in $500 \mu \mathrm{l}$ sterile distil water, mixed with $100 \mu \mathrm{l}$ buffer (1 $\mathrm{mM}$ EDTA, $10 \mathrm{mM}$ Tris- $\mathrm{HCl}, 50 \mathrm{mM} \mathrm{NaCl}, 10 \%$ sodium dodecyl sulfate and $5 \mu$ l of proteinase K), Vortex and incubated in water bath at $65^{\circ} \mathrm{C}$ for $5 \mathrm{~min}$, then centrifuged for $5 \mathrm{~min}$ at $3500 \mathrm{~g} / \mathrm{min}$.

\section{DNA extraction:}

Br. melitensis DNA was extracted using commercial DNA extraction kit (Sacace Biotechnologies Srl, Italy). According to manufacture instructions, $1.5 \mathrm{ml}$ polypropylene tubes were used, $300 \mu$ of lysis solution and $100 \mu \mathrm{l}$ of the samples added to each tube, Vortex and incubated at $65^{\circ} \mathrm{C}$ for $5 \mathrm{~min}$. All tubes centrifuged at $14000 \mathrm{~g}$ for $5 \mathrm{~min}$. The supernatant carefully transferred by a micropipette into new clean and sterile tubes, then $20 \mu \mathrm{l}$ of Sorbent added to each tube and incubated at room temperature for $3 \mathrm{~min}$, then centrifuged at $5000 \mathrm{~g}$ for $30 \mathrm{sec}$. The supernatant carefully removed and discarded. Thereafter, $300 \mu \mathrm{l}$ washing Solution 1 added to each tube, vortex vigorously and centrifuged at $8000 \mathrm{~g}$ for $30 \mathrm{sec}$, , then the supernatant removed and discarded. Then $500 \mu \mathrm{l}$ washing solution 2 added, vortex vigorously and centrifuged at $8000 \mathrm{~g}$ for $30 \mathrm{sec}$, then the supernatant removed. The pellet was resuspended in $50 \mu \mathrm{l}$ of DNAeluent, incubated at $65^{\circ} \mathrm{C}$ for $5 \mathrm{~min}$ and vortex periodically. The tubes centrifuged at maximum speed $12000 \mathrm{~g}$ for $1 \mathrm{~min}$ to recover the DNA, which existed in the supernatant and became ready for amplification.

\section{DNA Amplification:}

For amplifying $\mathrm{Br}$. melitensis DNA, the primers were used as an essential PCR elements which give bands (731 $\mathrm{bp}$ ), and the primers sequences were 5'-AAA, TCG, CGT, CCT, TGC, TGG, TCT, GA-3' and the reverses were 5'-TGC, CGA, TCA, CTT, AAG, GGC, CTT,
CAT-3' (Mohammad, 2006). The amplification reaction mixture (final volume: $25 \mu \mathrm{l}$ ) includes: $2.5 \mu \mathrm{l}$ PCR buffer [10 mM Tris- $\mathrm{HCl}$ (pH 8), $50 \mathrm{mM} \mathrm{KCl} \mathrm{,} 1.5 \mathrm{mM} \mathrm{MgCl}_{2}$ ], $2.5 \mu \mathrm{l}$ deoxynucleoside triphosphate $(200 \mu \mathrm{M})$ (Germany, Eppendrof), $2.8 \mu \mathrm{l}$ foreword primer, $2.6 \mu \mathrm{l}$ reverse primer, $1 \mathrm{U}$ of Taq DNA polymerase (Germany, Eppendrof), and $100 \mathrm{ng}$ genomic DNA. The volume was completed to $25 \mu \mathrm{l}$ with deionized distil water.

The amplification was carried out by the thermalcycler (Germany, Eppendrof) according to the commercial kit (Sacace Biotechnologies Srl, Italy). The following program was started when the temperature reaches $95^{\circ} \mathrm{C}$ : one cycle at $93^{\circ} \mathrm{C}$ for $5 \mathrm{~min}, 40$ cycles of $90^{\circ} \mathrm{C}$ for 60 sec, $60{ }^{\circ} \mathrm{C}$ for $60 \mathrm{sec}, 72^{\circ} \mathrm{C}$ for $60 \mathrm{sec}$. the final incubation was one cycle at $72^{\circ} \mathrm{C}$ for $10 \mathrm{~min}$.

Analysis of results was based on the presence or absence of specific bands of amplified DNA in agarose gel $2 \%$ (U.S.A., Ammersham Bioscience) stained with ethidum bromide. The length of specific amplified DNA fragments for $\mathrm{Br}$. melitensis (731 bp) was visualized using Gel documenting system.

\section{Statistical Analysis}

The data was analyzed statistically using SPSS 16.0 (SPSS, 2007). The Goodness-of-fit between RBPT and PCR was measured by McNemar's Chi-square test (Ott and Longnecker, 2004), whereas the agreement between the two was identified using Kappa Statistic (Viera and Garrett, 2005).

\section{RESULTS}

The total number of animals that gave positive reaction by RBPT was 35 out of 50 serum samples $(70 \%)$, while by PCR was 34 out of 50 milk samples (68\%). Statistically, this result indicates no significant difference between RBPT and PCR $(\mathrm{P}<0.01)$.

The agreement between RBPT and PCR was measured by comparing the results of the two tests in each animal of this study. The observed agreement was $0.66(66 \%)$, while Kappa was 0.206 indicating slight agreement between the two tests (Table 1).

Table 1: Comparison between the number and percentage of the RBPT and PCR results in 50 sheep.

\begin{tabular}{|c|c|c|c|}
\hline RBPT & \multirow[t]{2}{*}{ Positive } & \multirow[t]{2}{*}{ Negative } & \multirow{2}{*}{$\begin{array}{c}\text { PCR } \\
\text { Total Result }\end{array}$} \\
\hline PCR & & & \\
\hline Positive & $26(74.3 \%)^{*}$ & $8(53.3 \%)$ & $34(68 \%)$ \\
\hline Negative & $9(25.7 \%)$ & $7(46.7 \%) * *$ & $16(32 \%)$ \\
\hline RBPT Total Result & $35(70 \%)$ & $15(30 \%)$ & 50 \\
\hline \multicolumn{4}{|c|}{$\begin{array}{l}\text { * indicates the number of animals that gave positive result in both RBPT and PCR in samples from the same } \\
\text { animal. } \\
\text { ** indicates the number of animals that gave negative result in both RBPT and PCR in samples from the same } \\
\text { animal. }\end{array}$} \\
\hline
\end{tabular}

DNA amplification of $\mathrm{Br}$. melitensis using Species-specific Primers electro-phorized on (1.2\%) agarose gel indicates positive sample that showed single band of 731 bp (Fig. 1). 


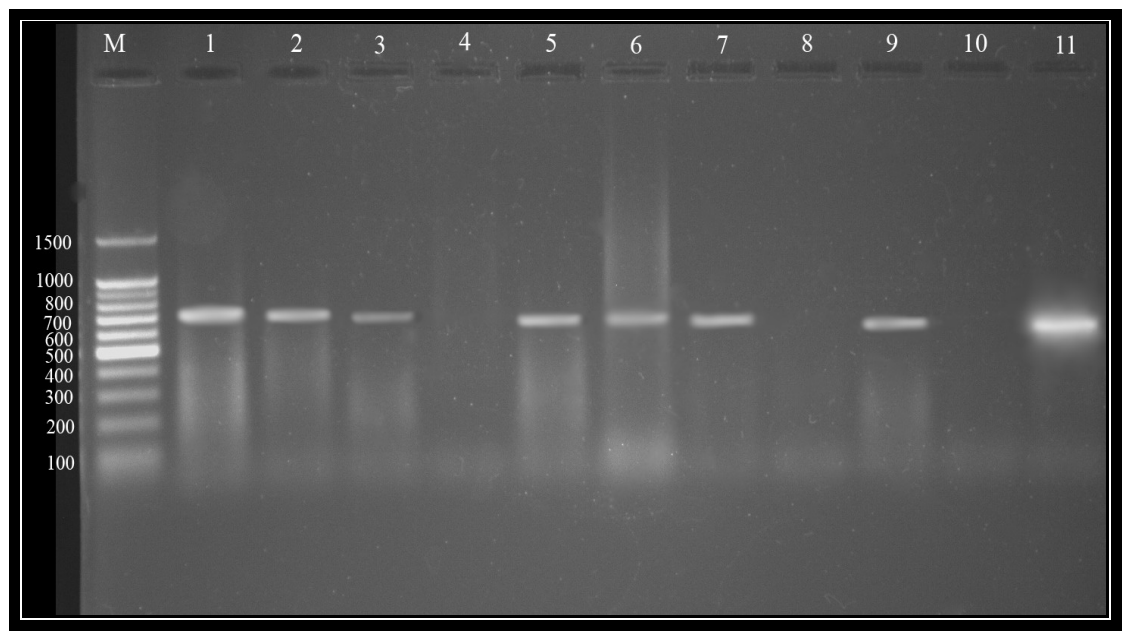

Fig. 1: Result of DNA amplification of Br. melitensis using Species-specific Primers electrophorized on (1.2\%) agarose gel. A single band of $731 \mathrm{bp}$ in lanes $(1,2,3,5,6,7,9,11)$ indicates positive sample, while lanes $(4,8,10)$ representing negative samples. Lane (M) indicates the DNA Ladder 100bp as DNA marker.

\section{DISCUSSION}

Brucellosis is a major zoonotic disease endemic in many parts of the world. It is characterized by chronic infection in animals leading to abortion and infertility. The disease is caused by Brucella which is gram negative, non spore forming, facultative intracellular organism (Cardoso et al., 2006).

In the present study, a PCR has been compared with one of serological methods for detection of brucellosis, RBPT is the most sensitive and rapid screening test used in detection of Brucella infection in animals, but it may produce false-positive and false-negative results (Ilhan et al., 2008). PCR has been used as an accurate and sensitive assay for detection of Brucella spp in a wide variety of clinical samples even if samples contain low number of brucella (Anonymous, 2001; Dehkordi et al., 2012).

In this research, there were differences between results of RBPT and PCR (Table 1). Studying milk samples using PCR to same animals their serums gave positive reactions by RBPT indicates that $74.3 \%$ positive with both tests (Table 1), which confirm that the infection of that animals caused by Br. melitensis, since we used one pairs of specific primers for the strain of Br. melitensis. Furthermore, there was $25.7 \%$ of milk samples presented negative reaction by PCR, while their samples gave positive reaction by RBPT (Table 1), which may assign to antibodies of other bacteria, not Br. Melitensis, or may produced due to $B$. abortus $\mathrm{S} 19$ vaccination or exposure to gram-negative bacteria, including include Vibrio cholerae O1, E. coli O:157, Salmonella group N (O:30) and Yersinia enterocolitica O:9, which has lipopolysaccharide (LPS) O-chains similar to those of brucellae (Charisis, 1998, OIE, 2004, Munoz et al., 2005).
Furthermore, Out of 15 animals their serum negative by EBPT there were $8(53.3 \%)$ milk samples positive by PCR (Table 1) which may indicates early incubation of disease that results in false negative RBPT (Radostits et al., 2007 ). Furthermore, the false negative of RBPT in this research me referred to testing of animals immediately after abortion, since many of owners test their animals immediately after abortion. On the other hand, there were 7 milk samples (46.7\%) present negative reaction by PCR out of 35 animals their serum also negative by EBPT (Table 1).

According to results of present research, the percentage of $\mathrm{Br}$. melitensis infection in aborted ewes in Nineveh is $68 \%$, which support by Anonymous (2001) who indicates that $\mathrm{Br}$. melitensis is the main etiological agent of brucellosis in small ruminants. Furthermore, presence of positive results on milk sample by PCR means that the animals shed the bacteria in their milk, since PCR detect the organism itself (Ilhan et al., 2008) and the PCR was found highly sensitive and specific for identification of Brucella from milk even if as low as 40 cells $/ \mathrm{ml}$ of milk (Romero et al., 1995).

The study concluded that using an accurate tests, such as species-specific PCR technique, is an important for reflecting an accurate incidence; since PCR revealed that $B r$. melitensis existed in aborted ewe's milk in a high percentage in Nineveh, Iraq, which has a public health importance.

\section{REFERENCES}

Abd El-Razik, KA.; Ghazi, YA. and Salama, EM. (2007): Monitoring of brucella does following milk examination using different techniques. Pak J Biol Sci; 10 (2): 240-244.

Al-Farwachi, MI.; Al-Badrani, BA. and Al-Nima, ThM. (2010): Detection of Brucella antigen in the 
aborted ovine fetal stomach contents using a modified ELISA test. Iraqi J. Vet. Sci; 24(1): 1-4.

Al-Farwachi, MI.; Al-Iraqi, OM.; Al-Hankawe, OKh. and Abdul-Majeed, MO. (2009): Using of competitive ELISA in detection of brucella antibodies in cattle sera in Mosul city, Iraq. Iraqi J Vet Sci; 23 (2): 97-103.

Al-Obaidi, QT.; Hassan, SD.; Mohammad, BA. and Arslan, SH. (2009): Prevalence of brucellosis using indirect ELISA test in raw milk in individual cases of ewes and does in Mosul city. Iraqi J. Vet. Sci; 23(2): 111-114.

Anonymous (2001): Brucellosis in sheep and Goats (Brucella melitensis). European Comission. Scientific Committee on Animal Health and Animal Welfare. Doc SANCO. C.2/AH/R23/2001.

Cardoso, PG.; Macedo, GC.; Azevedo, V. and Oliveira, SC. (2006): Brucella spp noncanonical LPS: structure, biosynthesis, and interaction with host immune system. Microbial Cell Factories; 5: $1-11$.

Celebi (2007): Cited by: Ibrahim AK, AbdelAll AA, Amin AS (2012): Long-Term Diagnostic Studies for Detection of Brucella spp. in Milk Samples. Global Veterinaria; 8(1): 54-61.

Charisis, NS. (1998): Human and animal brucellosis: epidemiological surveillance in the MZCP countries. Report of a WHO/MZCP workshop, Damascus, Syrian Arab Republic, 4-5 May/1998.

Culter (2005): Cited by: Ibrahim AK, AbdelAll AA, Amin AS (2012). Long-Term Diagnostic Studies for Detection of Brucella spp. in Milk Samples. Global Veterinaria; 8(1): 54-61.

Dehkordi, FS.; Saberian, S. and Momtaz, H. (2012): Detection and Segregation of Brucella abortus and Brucella melitensis in Aborted Bovine, Ovine, Caprine, Buffaloes and Camelid Fetuses by Application of Conventional and Real-time Polymerase Chain Reaction. Thai J. Vet. Med.; 42(1): 13-20.

Ibrahim, AK.; AbdelAll, AA. and Amin, AS. (2012): Long-Term Diagnostic Studies for Detection of Brucella spp. in Milk Samples. Global Veterinaria; 8(1): 54-61.

Ilhan, Z.; Solmaz, H.; Aksakal, A.; Gulhan, T.; Ekin, IH. and Boynukara, B. (2008): Detection of Brucella melitensis DNA in the milk of sheep after abortion by PCR assay. Arch. Med. Vet.; 40: 141-146.

Kazemi, B.; Yousefi Namin, SA.; Dowlatshahi, M.; Bandepour, F.; Kafilzadeh, L.; Gachkar, F.; Mohamoudinejad, A.; Samarghandi, $A$ and Mardani, M. (2008): Detection of Brucella by peripheral blood PCR and comparison with culture and serological methods in suspected cases .Iranian J. Public Health; 37: 96-102.

Mohammad, HA. (2006): Detection of Brucellosis in Sheep Using PCR With Other Serological Tests. MSc. thesis, college of Vet Med, University of Mosul.

Munoz, PM.; Marin, CM.; Monreal, D.; Gonzalez, D.; Garin-Bastuji, B.; Diaz, R.; Mainar-Jaime, RC.; Moriyon, I. and Blasco, JM. (2005): Efficacy of several serological tests and antigens for diagnosis of bovine brucellosis in the presence of falsepositive serological results due to Yersinia enterocolitica O:9. Clin Diag Lab Immunol; 12(1): 141-151.

OIE (2004): Manual of Diagnostic tests and vaccines for Terrestrial animal: Chapter 2.3.1: Bovine Brucellosis. http://www.oie.int

Ott, RL. and Longnecker, MT. (2004): A first course in statistical methods. Brooks/Cole, a division of Thomas Learning, Inc., USA, pp. 470-473.

Radostits, OM.; Gay, CC.; Hinchcliff, KW. and Constable, PO. (2007): Veterinary medicine. A textbook of the diseases of cattle, sheep, pigs and horses. $10^{\text {th }}$ ed. Saunders Elsever. London; 971-972.

Refai, M. (2003): Application of biotechnology in the diagnosis and control of brucellosis in the Near East Region. World J. Microbiol Biotechnol; 19, 443-449.

Rhaymah, MS.; AL-Saad, KM. and AL-Hankawe, OKh. (2010): Diagnosis of bovine brucellosis in Mosul city by indirect ELISA and conventional serological tests. Iraqi J. Vet. Sci.; 24(1): 1-6.

Romero, C. and Lopez-Goni, I. (1999): Improved Method for Purification of Bacterial DNA from Bovine Milk for Detection of Brucella spp. by PCR. Appl. Environ. Microbiol.; 65(8): 3735-3737.

Romero, C.; Pardo, M.; Grillo, MJ.; Diaz, R.; Blasco, JM. and Lopez-Goni, I. (1995): Evaluation of PCR and indirect enzyme-linked immune sorbent assay on milk samples for diagnosis of brucellosis in dairy cattle. Journal of Clinical Microbiology; 33: 3198-3200.

SPSS (2007): Statistical Package for the Social Science Advance Statistic ${ }^{\mathrm{TM}}$ Version 16.0. SPSS Inc., an IBM Company, Chicago, IL.

Viera, AJ. and Garrett, JM. (2005): Understanding interobserver agreement: the kappa statistic. Family Medicine: Research Series; 37(5): 360363. Available from: http://www.stfm. org/fmhub/ fm2005/May/Anthony360.pdf . 


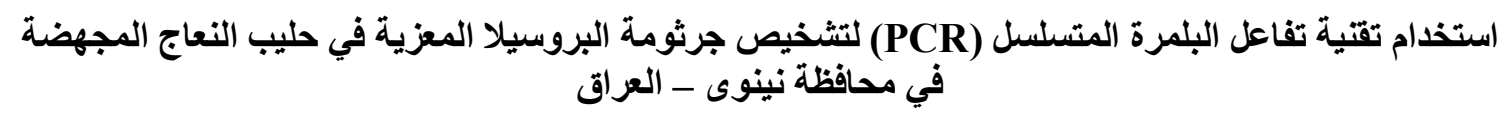

رعد عبد الغني السنجزي ، هديل عاصم محمد ، محد أسامة عبد المجيا

Email: ralsanjary61@yahoo.com

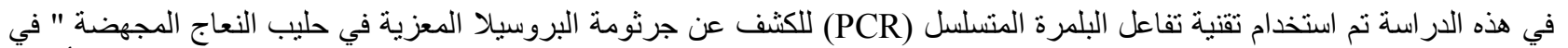

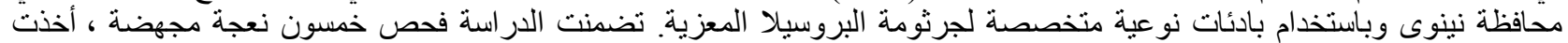

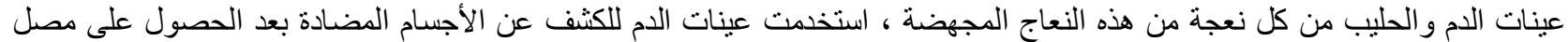

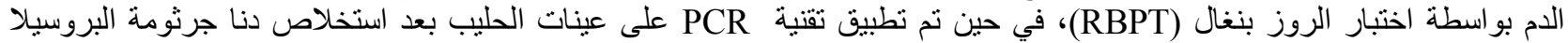

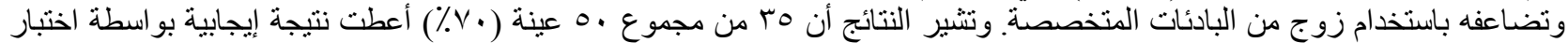

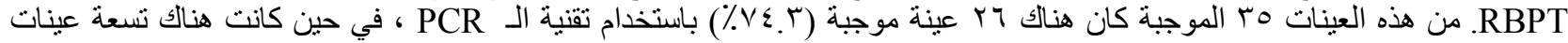

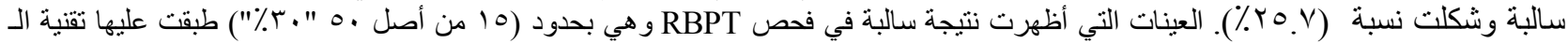
PCR

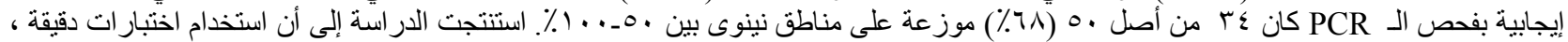

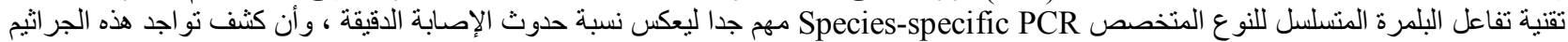
في حليب النعاج المجهضة ولنية البنة عالية في نينوى و العر اق له أهمية كبيرة على الصحة العامة. 